\title{
Microbial biogeography during austral summer 2007 in the surface waters around the South Shetland Islands, Antarctica
}

\author{
Lasse Mork Olsen ${ }^{1, *}$, Murat Van Ardelan ${ }^{2}$, Christopher D. Hewes ${ }^{3}$, \\ Osmund Holm-Hansen ${ }^{3}$, Christian Reiss ${ }^{4}$, Nihayet Bizsel ${ }^{5}$, Egil Sakshaug ${ }^{1}$, \\ Olav Vadstein ${ }^{6}$ \\ ${ }^{1}$ Department of Biology, and ${ }^{2}$ Department of Chemistry, Norwegian University of Science and Technology (NTNU), \\ Trondheim 7491, Norway \\ ${ }^{3}$ Polar Research Program, Marine Biology Research Division, Scripps Institution of Oceanography, \\ University of California-San Diego, La Jolla, California 92093-0202, USA \\ ${ }^{4}$ NOAA Fisheries, Antarctic Ecosystem Research Division, La Jolla, California 92037, USA \\ ${ }^{5}$ Institute of Marine Sciences and Technology, Dokuz Eylul University, Baku Bulvari No. 100 Inciralti, 35340 Izmir, Turkey \\ ${ }^{6}$ Department of Biotechnology, Norwegian University of Science and Technology (NTNU), Trondheim 7491, Norway
}

\begin{abstract}
Recent studies have concluded that different water bodies in the ocean can contain different microbial communities. The goal of the present study was to determine if biogeographic patterns are present for aquatic microbes in waters which meet around the South Shetland Islands (SSI), Antarctica. Prokaryotic and eukaryotic marine microbial communities were monitored during the 2007 austral summer by use of polymerase chain reaction (PCR) and denaturing gradient gel electrophoresis (DGGE) of small subunit ribosomal DNA. Hydrographic properties, nutrients and chlorophyll $a$ were also measured. There was an onshore to offshore gradient in temperature, salinity and iron concentration and a unimodal distribution of chlorophyll a concentration in relation to the middle of this gradient that occurred near the SSI. The differences in microbial community structure among stations in the studied area were correlated with both geographical distance and environmental factors. For eukaryotes, the correlation was strongest for environment, whereas it was strongest for geographical distance for the prokaryotes. Eukaryotic and prokaryotic community structures were highly correlated. Surface water from the Weddell Sea had a different community of eukaryotes than the water in the Antarctic Circumpolar Current in the Drake Passage, whereas the prokaryotic community was not significantly different. The area close to the SSI where the 2 water types mix had the highest chlorophyll concentration and significantly different communities of eukaryotes and prokaryotes from both of the inflowing water types. These results suggest that the prokaryote community structure was more affected by productivity than by environmental variables.
\end{abstract}

KEY WORDS: Microbial biogeography - Microbial community · Natural iron enrichment · Southern Ocean

\section{INTRODUCTION}

The question of whether all microbes are everywhere due to high dispersal abilities (Finlay 2002, Martiny et al. 2006) may be particularly apt for the marine pelagic environment, with its constantly moving habitats. Hydrographic properties like temperature and salinity create distinguishable water bodies that are driven by wind and thermohaline circulation (Emery 2001). Several studies have concluded that 
different adjoining water bodies in the ocean contain different microbial communities (e.g. Pinhassi et al. 2003, Díez et al. 2004, Hamilton et al. 2008). This could be due to different origin or past events and adaptations in communities separated in space and time or to the present environment selecting a certain community (Martiny et al. 2006, Lindström \& Langenheder 2012).

In the South Shetland Islands (SSI) area, Weddell Sea shelf water (WSSW) flows into the Bransfield Strait over the shelf of the Antarctic Peninsula, flowing both toward the southwest along the peninsula shelf and in a northerly direction toward Elephant Island (Fig. 1). The current wraps northeastwardly at the southwestern extent of the Bransfield Strait to flow along the shelves of the SSI toward Elephant Island. To the north of the SSI lies the Drake Passage, where the westerlies drive the Antarctic Circumpolar Current (ACC) in an eastward direction (Fig. 1). During summer, ACC water flows into the Bransfield Strait through its entrance at the southwest (HolmHansen \& Hewes 2004, Hewes et al. 2009, Thompson et al. 2009). In our study area (Fig. 1), there are inshore to offshore gradients in temperature, salinity and both micro- and macro-nutrients (Hewes et al. 2008, 2009). The entire area is a high nutrient, low chlorophyll (HNLC) region with relatively low phytoplankton biomass or primary production in contrast to the relatively high concentrations of nitrate $\left(\mathrm{NO}_{3}\right)$, phosphate $\left(\mathrm{PO}_{4}\right)$ and silicon (Si). The Weddell Sea and continental shelf water contains iron concentrations in the upper mixed layer (UML) that are relatively high (Sanudo-Wilhelmy et al. 2002, Hewes et al. 2008), whereas iron is low and potentially growth-limiting in the Drake Passage (Hopkinson et al. 2007, Hewes et al. 2008, Dulaiova et al. 2009, Ardelan et al. 2010). The iron-rich shelf waters flowing from the Weddell Sea into the Bransfield Strait also have a low chlorophyll a (chl a) concentration (a proxy for phytoplankton biomass) that is thought to be caused by deep mixing, which promotes light-limiting conditions (Hewes et al. 2008, 2009). Therefore, 2 different types of HNLC waters are found in the region: those of the ACC are due to low iron concentrations, while those under Weddell Sea influence are due to light-limitation (reviewed by Hewes 2010). The iron-rich water of the deep UML from the Weddell Sea mix with the warmer, stable but iron-deficient surface waters of the ACC in the area around the SSI, which results in the highest chl a concentrations for the entire region (Fig. 1).

In the present study, we monitored the entire microbial community of autotrophs and heterotrophic bacteria and protists. We used polymerase chain reaction (PCR) amplification and denaturing gradient gel electrophoresis (DGGE) of $18 \mathrm{~S}$ and $16 \mathrm{~S}$ small subunit ribosomal DNA (rDNA) for eukaryotic protists and prokaryotes, respectively, to make DNA fingerprints of the communities. Dissimilarity matrices of community data, geographical distance and environmental variables from the sampling area were used to test statistically if differences in communities were correlated with geographical distance and/or with differences in the environment. Finally, analysis of similarity (ANOSIM) was used to test the hypothesis that the 2 endpoint surface water zones and the middle confluence zone had different microbial communities.

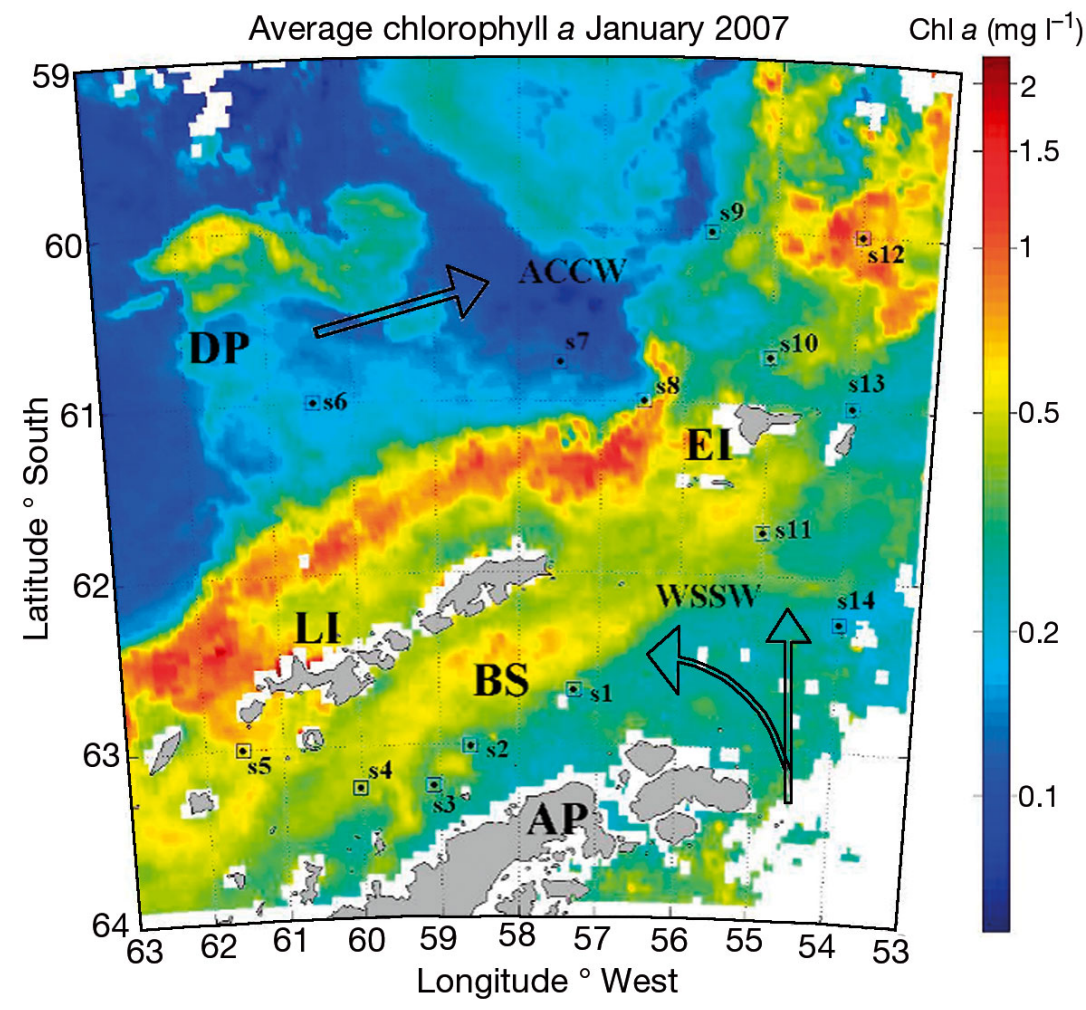

Fig. 1. The Antarctic Marine Living Resources study area with the 14 stations (s1-s14) sampled for the present study indicated. DP: Drake Passage; EI: Elephant Island; LI: Livingston Island; BS: Bransfield Strait; AP: Antarctic Peninsula; ACCW: Antarctic Circumpolar Current water; WSSW: Weddell Sea shelf water. Arrows indicate the main directions of the currents. Map shows average chlorophyll a $\left(\mathrm{mg} \mathrm{m}^{-3}\right)$ during January 2007 calculated from ocean colour measured by the MODIS satellite 


\section{MATERIALS AND METHODS}

\section{Study area and sampling}

All sampling was performed during the 2007 Antarctic Marine Living Resources (AMLR) cruise aboard RV 'Yuzhmorgeologiya' in the period January 11 to January 25. The AMLR sampling grid consists of 99 routine sampling stations in the area surrounding the South Shetland Islands, Antarctica. We sampled at 14 of these stations (Fig. 1). The numbers 1 to 14 denote the chronological order of the samplings. The whole sampling tour took $15 \mathrm{~d}$. Water column samples were collected with a Sea-Bird conductivity, temperature and depth (CTD) carousel water sampler equipped with 101 Niskin bottles (Reiss et al. 2009). Our samples were collected at $20 \mathrm{~m}$ depth, except iron samples, which were taken at $25 \mathrm{~m}$ with GO-FLO bottles. The depth of the UML $\left(Z_{\mathrm{UML}}\right)$ was defined as the depth at which the density differed by $0.05 \mathrm{~kg} \mathrm{~m}^{-3}$ from the mean potential density measured between 5 and $10 \mathrm{~m}$ depth. Water samples for dissolved iron measurements were collected with acid-cleaned teflon-lined GO-FLO bottles deployed on trace-metal clean polymer ${ }^{1 / 4}$ inch $(\sim 6.4 \mathrm{~mm})$ Sta-Set X linen (New England Ropes) line using a dedicated winch. Samples for phytoplankton counts $(200 \mathrm{ml})$ were fixed with buffered formalin to a final concentration of $1 \%$ and stored until analysis. Samples for PCR-DGGE were collected by filtering 60 to $100 \mathrm{ml}$ of the sample through $0.2 \mu \mathrm{m}$ hollow fiber syringe filters (DynaGard, Microgon) and freezing at $-20^{\circ} \mathrm{C}$ until further analysis.

\section{Chemical analysis}

For nutrient analyses, water from the CTD was collected in acid-washed $60 \mathrm{ml}$ high-density polyethylene bottles and immediately frozen at $-20^{\circ} \mathrm{C}$. The samples were analysed for $\mathrm{NO}_{3}, \mathrm{PO}_{4}$ and Si concentration by an auto-analyzer within 1 to 3 mo after sampling. These samples were missing for Stns 4 and 14. To avoid missing values in the statistical analyses, the averages of the 2 closest stations were used. Processing of the samples for iron analysis was conducted according to Ardelan et al. (2010), and iron concentration was measured with a high-resolution inductive coupled plasma mass spectrometer (HRICP-MS) Element 2 (Thermo-Finnigan). The concentration of chl a was determined by a fluorometric method after extraction in methanol (Holm-Hansen \& Riemann 1978). Fluorescence was measured with a Turner Designs 700 fluorometer.

\section{DNA extraction, PCR and DGGE}

DNA was extracted from the filters according to the protocol described in the DNeasy tissue kit handbook (Qiagen), 'Isolation of DNA from gram negative bacteria'. To ensure sufficient DNA concentration for PCR, the first eluting step was performed with $50 \mu \mathrm{l}$ water instead of $200 \mu \mathrm{l}$ as suggested in the protocol. The variable V3 region of the bacterial 16S rDNA was amplified using the forward primer $338 \mathrm{f}$ (5'-ACT CCT ACG GGA GGC AGC AG-3') (Ovreås et. al. 1997), with a $40 \mathrm{bp}$ guanine and cytosine-rich sequence (GC)-clamp (5'-CGC CCG CCG CGC GCG GCG GGC GGG GCG GGG GCA CGG GGG G-3') (Muyzer et al. 1993) attached to the 5' end, and the reverse primer Pru517r (5'-ATT ACC GCG GCT GCT GG-3') (Muyzer et al. 1993). For eukaryotic rDNA, we used the 18S ribosomal DNA-specific primer set Euk1A and Euk516r-GC, which amplifies a fragment 560 bp long (Díez et al. 2001). The PCR was performed under the following conditions in a $50 \mu \mathrm{l}$ volume: 1 buffer (Qiagen), $15 \mu \mathrm{g}$ BSA (Sigma Aldrich), $200 \mu \mathrm{M}$ dNTP (Qiagen), $1.5 \mathrm{mM} \mathrm{MgCl}_{2}$ (Qiagen), $0.4 \mu \mathrm{M}$ primers (each), $0.4 \mathrm{U}$ Taq DNA Polymerase (Qiagen) and $5 \mu$ template DNA. The reaction was initiated with a step at $95^{\circ} \mathrm{C}$ for $4 \mathrm{~min}$, followed by 30 cycles of $1 \mathrm{~min}$ at $95^{\circ} \mathrm{C}, 1 \mathrm{~min}$ at $55^{\circ} \mathrm{C}$ and $1.5 \mathrm{~min}$ at $72^{\circ} \mathrm{C}$ and finally an extension step at $72^{\circ} \mathrm{C}$ for $6 \mathrm{~min}$. To verify the presence of fragments of the correct size, $5 \mu \mathrm{l}$ PCR products were analysed on a $1 \%$ agarose gel stained with ethididum bromide. DGGE was performed with an Ingeny phorU system. The denaturating gradient ranged from 25 to $55 \%$ for $16 \mathrm{~S}$ and from 30 to $40 \%$ for $18 \mathrm{~S}$ in an $8 \%$ (w/v) acrylamide gel. In total, $15 \mu$ PCR products were loaded onto the gel, and the electrophoresis was run at $100 \mathrm{~V}$ and $60^{\circ} \mathrm{C}$ for $21 \mathrm{~h}$. The gel was stained for $1 \mathrm{~h}$ in SYBR Gold nucleic acid gel stain (1:10 000 dilution in 0.5 TAE, Molecular Probes) prior to visualization and photographing on a GelDoc system (BioRad). DGGE bands to be sequenced were excised, and the DNA fragments were eluted. The fragments were amplified by PCR using the primers $338 \mathrm{f}$ (no GC clamp) and 517R. The sequences were uploaded to the sequence match tool in the Ribosomal Datatbase Project (RDP) to search for the nearest neighbour (http://rdp.cme.msu.edu).

\section{Analysis of DGGE band patterns}

The DGGE band patterns were analysed with the Gel2k software v.1.2.6 (developed by S. Norland, University of Bergen, Norway). Some bands were 
manually assigned to classes common for all lanes because of distortion of the gel. The relative intensities of the bands (peak area) compared to the background of the lanes were quantified by Gel2k. For each sample, the peak areas were normalized to the sum of the peak area.

\section{Statistical analysis}

Similarity matrices were constructed for the phytoplankton cell counts, the standardized relative frequency of DGGE band intensity, the environmental data from 20 or $25 \mathrm{~m}$ depth at each sampling station and the linear geographical distance between the stations. For phytoplankton counts and DGGE fingerprints, the Bray-Curtis similarity was calculated. The relative frequency matrices for DGGE bands were fourth-root transformed to reduce the impact of strong bands on the numerical analysis. For environmental data, Euclidean distances were used according to Clarke (1993). The environmental matrix was standardized by the formula [( $\mathrm{n}-$ average $\mathrm{n}) / \mathrm{SD}]+3$ to correct for the widely differing scales of the measured variables.

The correlation between the dissimilarity matrices was assessed with Mantel tests. The DGGE dissimilarity matrices were used as the dependent matrix, and the geographical or the environmental dissimilarity were used as predictor matrices. The following questions were addressed: (1) Do samples taken close to each other geographically have similar community composition, and (2) Do similar environments also have similar community composition? The null hypothesis is that an observed correlation (Pearson) between the distance matrices can be obtained by a random arrangement. The test yields the Mantel $r$ statistic with a value between -1 and 1 . The significance of the statistic is evaluated by permutation of rows and columns in the dependent dissimilarity matrix. A partial Mantel test was used to compare 3 dissimilarity matrices, by comparing 2 matrices while controlling for the third. The test statistic was calculated by constructing matrices of the residuals of the regression between the first and the third and the second and the third and then comparing the 2 residual matrices with the standard Mantel test (Legendre \& Legendre 1998).

To test for significant differences in community composition and environmental variables between groups of sampling stations, we used the ANOSIM test. ANOSIM compares the ranks of similarities between and within groups. The means of the 2 types of ranks are compared, yielding the $R$ test statistic, which is 1 for total separation and 0 for no separation (Clarke 1993). Numerical analyses were performed with various packages in the R 2.7.1 platform (R Development Core Team 2008).

\section{RESULTS}

\section{Hydrography and environmental variables}

There was a linear relationship between temperature and salinity, with opposite gradients (Fig. 2a). The temperature range was between -0.55 and $1.99^{\circ} \mathrm{C}$, and the salinity range was 33.88 to $34.45 \mathrm{psu}$. Table S1 in the Supplement at www.int-res.com/ articles/suppl/a070p131_supp.pdf shows the data for all the environmental variables at $20 \mathrm{~m}$ depth and at the $Z_{\mathrm{UML}}$ for all sampling stations. The chl a concentration varied between 0.06 and $1.74 \mu \mathrm{g} \mathrm{l}^{-1}$ and was highest at the stations in the middle of the tem-
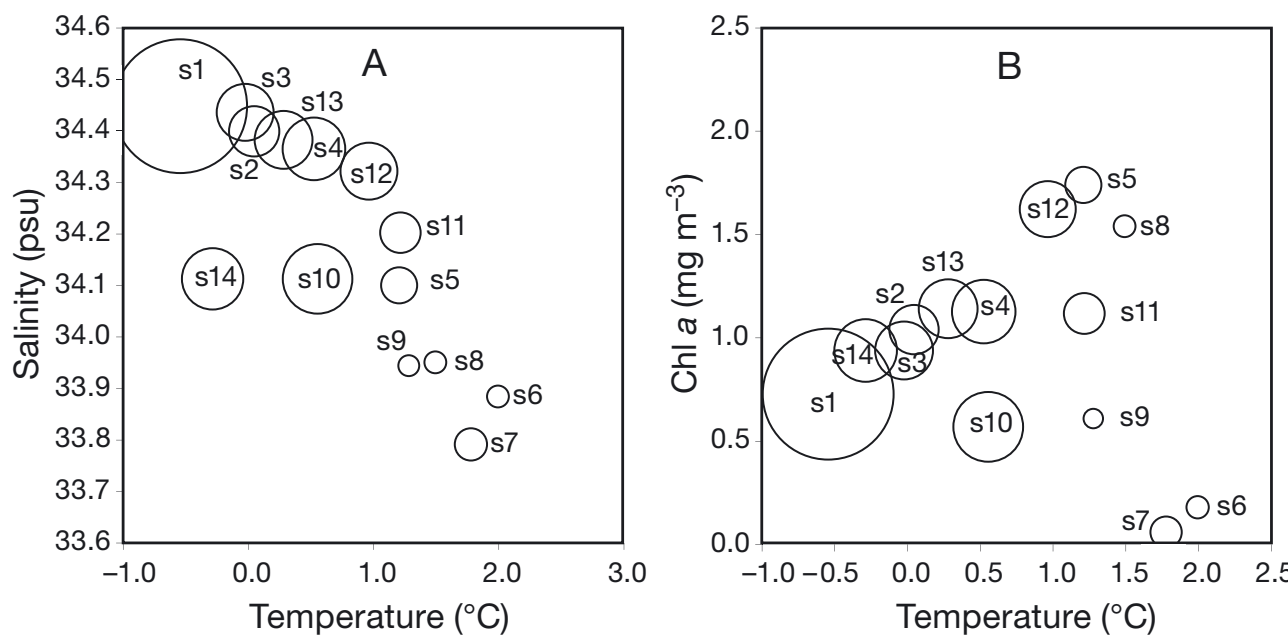

Fig. 2. (A) Salinity versus temperature with iron concentration (nM) shown by the bubble size at our sampling depth of $20 \mathrm{~m}(25 \mathrm{~m}$ for iron samples) and (B) chlorophyll a (chl a) concentration versus temperature with iron concentration shown by the bubble size at the sampling depth. Station numbers (s1-s14) are indicated 
perature-salinity gradient, i.e. Stns 5, 8 and 12 (1.54 to $1.74 \mu \mathrm{g} \mathrm{l}^{-1}$ ). These stations had temperatures between 1 and $1.5^{\circ} \mathrm{C}$ and salinity between 34.0 and 34.3 psu (Fig. 2a, Table S1). The other stations with lower or higher temperature and salinity had chl $a$ concentrations between 0.29 and $1.14 \mu \mathrm{g} \mathrm{l}^{-1}$, with the lowest values at high temperature/low salinity sites (Fig. 2b, Table S1). The iron concentration was in the range 0.12 to $5.16 \mathrm{nM}$ and is shown by the size of the bubbles in Fig. 2. The iron concentration was highest in the low temperature/high salinity end of the gradient (Fig 2a). $Z_{\mathrm{UML}}$ was between 23 and $146 \mathrm{~m}$ (Table $\mathrm{S} 1$ ). $\mathrm{NO}_{3}, \mathrm{Si}$ and $\mathrm{PO}_{4}$ concentrations were in the ranges $25.50-29.40,23.00-77.00$ and $1.87-2.57 \mu \mathrm{M}$, respectively (Table $\mathrm{S} 1$ ).

Temperature-salinity diagrams for the water column (Fig. 3) indicated that Stns 1 to 4 (Fig. 1) consisted of WSSW, and Stns 6 to 9 (Fig. 1) were in Antarctic Circumpolar Current water (ACCW) according to the classification used in the AMLR program (Holm-Hansen et al. 1997, Lipsky 2007). We used a simpler protocol than described for the AMLR program for both transition and Bransfield Strait waters as a combined mixed water type (MIXW; Table S1) that occurred at Stns 5, 10, 11, 12, 13 and 14 (Fig. 1). Temperature was significantly higher in ACCW stations compared to WSSW and MIXW, and salinity was significantly different among all water masses and highest in WSSW. The $\mathrm{N}$ and Si concentration was significantly lower in ACCW than in WSSW and MIXW. The iron concentration was significantly lower in ACCW than in WSSW (ANOVA, p < 0.05).

Table S2 in the Supplement shows the Pearson correlation coefficient (r) matrix for all the environmental variables $(\mathrm{p}<0.05)$. Temperature and salinity were negatively correlated. Iron, $\mathrm{NO}_{3}$ and $\mathrm{Si}$ were negatively correlated with temperature and positively correlated with salinity, i.e. were present at lowest concentration in offshore waters. There was a strong but not significant correlation between iron and $Z_{\mathrm{UML}}$, but this was partly because of a very high iron concentration and very deep $Z_{\mathrm{UML}}$ at Stn 1 (Table S1).

\section{DGGE}

The total number of unique DGGE band positions detected on the gels was 26 for both $16 \mathrm{~S}$ and $18 \mathrm{~S}$ rDNA. For 16S, the number of bands in individual samples varied between 15 and 23 bands. Bands cut out for sequencing are marked in Fig. S1 in the Supplement.
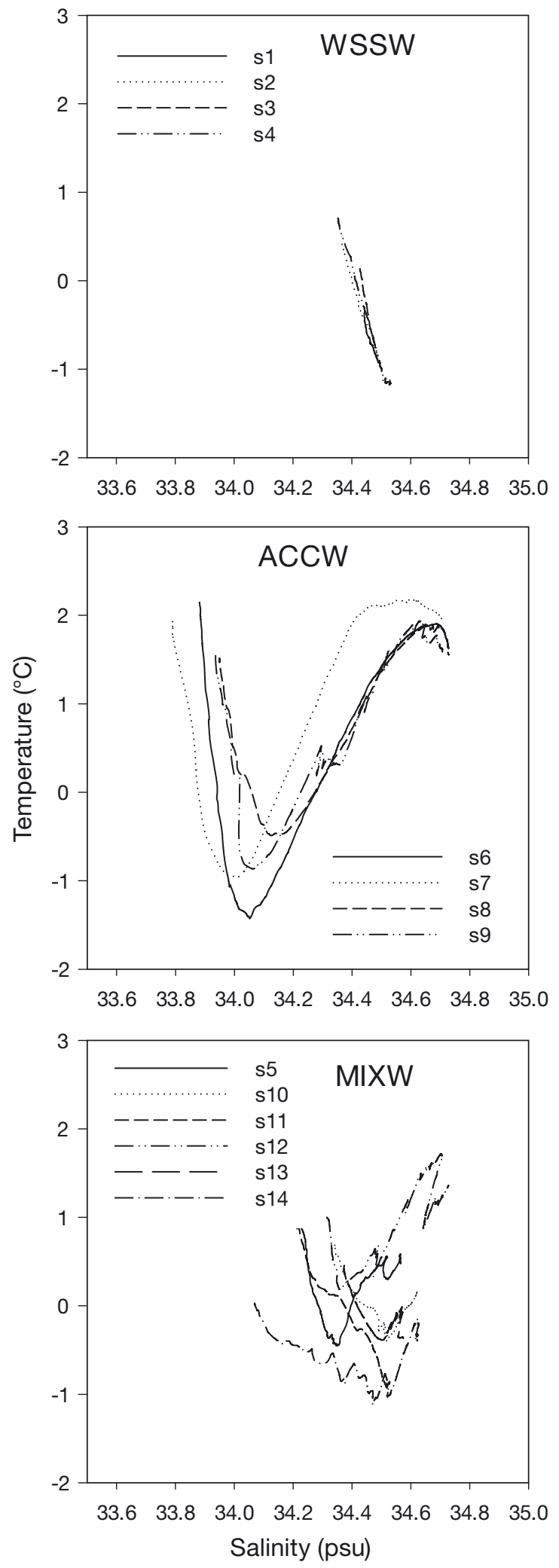

Fig. 3. Temperature vs. salinity in the depth profiles from the sampling stations (s1-s14) grouped according to identified water mass: Weddell Sea shelf water (WSSW); Antarctic Circumpolar Current water (ACCW); and mixed water (MIXW) 
The results from the search for the nearest neighbour in the Ribosomal Database Project (http://rdp. cme.msu.edu) are summarized in Table S3 in the Supplement. Most of the sequences were very short (Table S3) and unsuitable for taxonomic analysis. Five of the bands were identified as possible chloroplasts (Table S3). These DGGE bands were excluded from the further analyses of the $16 \mathrm{~S}$ fingerprint. On the DGGE gel for the 18S rDNA, a part of the gel could not be analysed due to heavy distortion of the bands. The region of the gel used in the further analysis contained 8 to 11 bands for individual samples (Fig. S2 in the Supplement).

\section{Mantel and ANOSIM tests}

The Mantel tests showed significant correlation between the DGGE fingerprint matrices and both the environmental dissimilarity and the geographical distance matrices for both the prokaryotic and eukaryotic communities (Table 1). The Mantel $r$ statistic was highest for DGGE vs. environment matrices for eukaryotes, but for the 16S DGGE, $r$ was highest for DGGE vs. geographical distance (Table 1). No signif-

Table 1. The Mantel $r$ statistic and the $\mathrm{p}$-value from the tests of correlation between dissimilarity matrices of community as DGGE fingerprints of eukaryotes (18S rDNA), prokaryotes (16S rDNA) and environmental variables and geographical distance. Y: DGGE fingerprint; Bray-Curtis dissimilarity matrix. X: environmental variables; Euclidean dissimilarity matrix. S: geographical distance; Euclidean dissimilarity matrix

\begin{tabular}{|lccccc|}
\hline \multirow{2}{*}{ Mantel test } & \multicolumn{3}{c}{ Eukaryotes } & \multicolumn{2}{c|}{ Prokaryotes } \\
& $r$ & $\mathrm{p}$ & $r$ & $\mathrm{p}$ \\
\hline YX & 0.500 & 0.001 & 0.214 & 0.046 \\
YS & 0.321 & 0.013 & 0.441 & 0.003 \\
Partial YX:S & 0.561 & $<0.001$ & 0.296 & 0.031 \\
Partial YS:X & 0.205 & 0.062 & 0.432 & 0.005 \\
\hline
\end{tabular}

Table 2. Test statistic $R$ from ANOSIM tests for dissimilarity of DGGE fingerprints for eukaryotes (18S rDNA) and prokaryotes (16S rDNA) and of environmental variables for the 3 water masses identified in the study area: Weddell Sea shelf water (WSSW); Antarctic Circumpolar Current water $(\mathrm{ACCW})$; and mixed water (MIXW). ${ }^{*} \mathrm{p}<0.05,{ }^{* *} \mathrm{p}<0.005$

\begin{tabular}{|lccc|}
\hline ANOSIM test & $\begin{array}{c}\text { WSSW } \\
\text { vs. ACCW }\end{array}$ & $\begin{array}{c}\text { WSSW } \\
\text { vs. MIXW }\end{array}$ & $\begin{array}{c}\text { ACCW } \\
\text { vs. MIXW }\end{array}$ \\
\hline Eukaryotes & $0.365^{*}$ & $0.512^{*}$ & $0.460^{*}$ \\
Prokaryotes & 0.354 & $0.496^{*}$ & $0.365^{*}$ \\
Environment & $0.979^{*}$ & 0.067 & $0.861^{* *}$ \\
\hline
\end{tabular}

icant correlation was found between the environment and geographic distance matrices $(r=0.021, \mathrm{p}=$ 0.368). According to the partial Mantel tests controlling for the effects of geographical distance, the residuals were significantly correlated for the DGGE vs. environment matrices for eukaryotes (Table 1). Mantel tests between the DGGE matrices for eukaryotes and prokaryotes showed significant correlation and a high Mantel $r$ value $(r=0.609, \mathrm{p}<0.001)$. According to the ANOSIM tests, the rDNA DGGE fingerprints were significantly different for all pairs except WSSW vs. ACCW for prokaryotes (Table 2). WSSW and MIXW were not significantly different with regard to environmental variables, whereas ACCW was significantly different from both WSSW and MIXW (Table 2).

\section{DISCUSSION}

\section{Community structure and environmental gradients in the study area}

PCR-DGGE detects all populations constituting more than 0.1 to $1 \%$ of the microbial community regardless of organism size down to the filter pore size of $0.2 \mu \mathrm{m}$ (Muyzer \& Smalla 1998, Fromin et al. 2002). Because of this, DGGE is suited for studying the dominant community but not the rare species. We could separate a maximum of 26 different DGGE bands for both 16S and 18S DGGE. Similar numbers were found by others in the Southern Ocean (Murray et al. 1998, Gast et al. 2004). The community detected by $18 \mathrm{~S}$ DGGE consists of both autotrophic and heterotrophic eukaryotes (Díez et al. 2004, Gast et al. 2004). 16S DGGE bands represent prokaryotes and in addition can contain some chloroplasts from eukaryotic algae because they also have $16 \mathrm{~S}$ ribosomal DNA. In the Southern Ocean, cyanobacteria are very low in numbers or absent and therefore not likely to be detected (Vincent et al. 2000).

For the total eukaryote community (18S DGGE) and prokaryotes (16S DGGE), there were correlations with both environmental variables and geographical distance, strongest for environment for the eukaryotes. The prokaryote community matrix had a higher Mantel $r$ value for the correlation with distance than for environment (Table 1). This suggests that the eukaryote community was more affected by the environment, whereas the prokaryote community was more affected by geographical distance (Table 1). Martiny et al. (2006) concluded from their literature survey that both spatial and environmental 
effects on community structure at the same time are most likely to be found at the intermediate distance scale of 10 to $1000 \mathrm{~km}$, as in this study, whereas separation in space and time become dominating forces at larger scales and environmental factors dominate at smaller scales. There are examples of differences in microbial communities within marine areas of medium size for prokaryotes detected with $16 \mathrm{~S}$ DGGE (Pinhassi et al. 2003) and for eukaryotes detected with 18S DGGE (Hamilton et al. 2008). One could imagine that rapid dispersal of microbes in an area of this size could be accomplished by e.g. hitchhiking with animals like fish, whales or birds that move rapidly compared with the water currents. However, this might not contribute enough microbes to alter the main structure of the community. The water entering our study area from the west in the ACC has presumably been separated from the water entering from the Weddell Sea in the southeast for several years. E.g. if the surface current speed is $20 \mathrm{~cm} \mathrm{~s}^{-1}$ in the ACC and the plankton follow a straight line around the ACC at a latitude of $60^{\circ} \mathrm{S}$, the time needed to encircle the whole globe would be $3.2 \mathrm{yr}$. The current and the plankton certainly do not go in a straight line, so the actual time would probably be considerably longer.

Temperature and salinity were negatively correlated (Table S2 in the Supplement), forming opposite gradients between the shelf of the Antarctic Peninsula and the Drake Passage (Fig. 2a). Jamieson et al. (2012) argued that in this area, temperature could be an important structuring factor. The temperature gradient had a range from -0.55 to 1.99 (Table S1), which implies that at least in the cold waters of the Weddell Sea, cold-adapted organisms might have an advantage which is not necessarily beneficial in the ACC waters. Salinity effects are less likely even if there was a gradient since the differences are very small. The correlation of both temperature and salinity reflects variation in the community composition across the gradients, which could also be caused by other factors.

The concentrations of $\mathrm{N}, \mathrm{Si}$ and $\mathrm{PO}_{4}$ (Table S1) confirm that the entire area is an HNLC region. The relatively high concentrations indicate that these nutrients were not limiting the growth of primary producers or bacteria (Vadstein 2011) and therefore were not likely to affect community structure. Iron was correlated with temperature and salinity, although not significantly (Table S2). Iron is expected to be an important structuring element because it is likely to be a limiting nutrient in parts of the area and not in other parts. The other primary candidate struc- turing environmental factor is $Z_{\mathrm{UML}}$, which could be important because deep $Z_{\mathrm{UML}}$ in the Weddell Sea and continental shelf area could lead to light-limited primary production there, whereas it is not likely in other parts of the study area (Hewes et al. 2009). We did not observe big differences in $Z_{\mathrm{UML}}$ at our stations. Only 2 stations had a deep mixed layer (Table S1). Our measurements indicated a unimodal distribution of chl a with highest concentration at intermediate temperature and salinity (Fig. 2b), which has been found to occur annually during summer over 2 decades (Hewes et al. 2008, 2009). These results support the hypothesis that relatively high iron concentration and shallow UML around the SSI results in higher productivity.

There was a strong correlation between $18 \mathrm{~S}$ and 16S Bray-Curtis dissimilarity matrices (Mantel $r=$ $0.609, \mathrm{p}<0.001$, respectively), which could be expected if there is a strong dependence between eukaryotes and prokaryotes. Because allochthonous input of organic matter is low in the Southern Ocean due to almost no freshwater input except from ice, heterotrophic bacteria depend on phytoplankton as the ultimate source of energy. Bacterial community composition often shows adaptation to the phytoplankton community (e.g. Pinhassi et al. 2004), and protozoan predators are known to have structuring effects on the community of their prey (Langenheder \& Jürgens 2001), which could be both bacteria and small eukaryotes. Protozoans have been found to comprise 7 to $75 \%$ of the total nano- and microplankton in Antarctic waters (Hewes et al. 1985, 1990, Garrison 1991). Because of ecological interactions in the plankton, external forces like environmental variables or internal forces like adaptations over time can structure the whole microbial community of prokaryotes and eukaryotes.

\section{Comparison of community structure and environment in three defined water types}

Temperature and salinity at our sampling depth of $20 \mathrm{~m}$ described the surface gradients in the area. In addition, we used temperature vs. salinity diagrams (Fig. 3) of entire depth profiles to identify different water bodies or zones (Holm-Hansen et al. 1997, Emery 2001, Hewes et al. 2008). We classified sampling Stns 1, 2, 3 and 4 in the southern part of the Bransfield Strait (Fig. 1) as WSSW and Stns 6, 7, 8, and 9 in the Drake Passage (Fig. 1) as ACCW. The remaining 6 stations all positioned in between WSSW and ACCW in the vicinity of the SSI we classified as 
MIXW. Our MIXW is simplified from the AMLR protocol, which separates several transition waters in the zone between the ACCW and the WSSW (HolmHansen et al. 1997, Lipsky 2007, Hewes et al. 2008).

MIXW had eukaryotic and prokaryotic microbial communities that were significantly different from those in ACCW and WSSW. Also, ACCW and WSSW had significantly different communities of eukaryotes but not of prokaryotes (Table 2), indicating that the bacterial communities are similar in the 2 water types during non-bloom conditions. High similarity in the prokaryote community has been observed by others in the same area. Jamieson et al. (2012) concluded that significant differences could be found only in the rare diversity. In the studies of natural iron enrichment in the Kerguelen area, the bacterial community as well as the phytoplankton community inside a bloom area was different from that outside (Armand et al. 2008, West et al. 2008). It was concluded that increased iron input stimulated bacterial productivity indirectly through enhanced primary production (West et al. 2008).

ACCW was significantly different from the other water types with respect to the total of the environmental variables measured in the UML, whereas MIXW and WSSW were not (Table 2). This suggests that the inflow of WSSW had a larger influence on the MIXW environment than the inflow of ACCW. In accordance with earlier studies, the iron concentration was highest in WSSW and lowest in ACCW (Sanudo-Wilhelmy et al. 2002, Hewes et al. 2008, Ardelan et al. 2010) and was correlated with salinity and temperature (Table S2). Iron limitation of primary production is likely in the ACCW and less likely in WSSW and MIXW (Hopkinson et al. 2007). According to Hewes et al. (2009), a deep mixed layer and light limitation of primary production is likely in WSSW. Only Stn 1 in WSSW and Stn 13 in MIXW had deep mixed layers (Table S1); the rest of the stations had relatively shallow mixed layers (Table $\mathrm{S} 1$ ).

To our knowledge, no previous study explicitly tested for differences in the microbial communities in water originating in the Weddell Sea, the ACC and the mixed water surrounding the SSI before. However, several studies of microbial community structure have been performed in the same area. Bodungen et al. (1986) defined 3 zones which coincide well with the areas of our 3 water types and found persistent differences in phytoplankton community structure as well as highest biomass in the middle area close to the SSI. Kang et al. (2001) divided the area into 2 regions - the Weddell Sea and the Bransfield Strait region-based on differences in the phyto- plankton communities and $Z_{\mathrm{UML}}$, which was generally deep in the Weddell Sea water. Two other studies of phytoplankton recognized the pattern of high $\mathrm{chl}$ a close to the SSI, lower in the Drake Passage and near the continental shelf influenced by Weddell Sea water, and they found differences in the communities (Olguin \& Alder 2011, Mendes et al. 2012). Mendes et al. (2012) concluded that water column stability (i.e. $Z_{\mathrm{UML}}$ ) determined phytoplankton community structure. Díez et al. (2004) studied variation in the eukaryotic picoplankton community in a transect from the northwest Weddell Sea to the Drake Passage and concluded that changes in the community were consistent with changes in density of the water; these authors found different communities in the Weddell Sea and the Bransfield Strait compared with the Drake Passage. Although none of these studies defined the sub-areas in exactly the same way, the results generally support the hypothesis that different water types or zones defined by hydrography in this area have different microbial communities.

\section{CONCLUSIONS}

The dissimilarity of prokaryotic and eukaryotic microbial community structure among stations in the studied area was correlated with both geographical distance and environmental variables. For eukaryotes, the correlation was strongest for environment, whereas it was strongest for geographical distance for the prokaryotes. Eukaryotic and prokaryotic community structure was highly correlated. Surface water entering the area from the Weddell Sea in the southeast had a different community of eukaryotes than the water entering from the west with the ACC, whereas the prokaryotic community was not significantly different. The area close to the SSI where the 2 water types mix had the highest chlorophyll concentration and significantly different communities of eukaryotes and prokaryotes from both of the inflowing water types. This suggests that the prokaryote community structure was more affected by productivity than by environmental variables.

Acknowledgements. Thanks to the crew on RV 'Yuzhmorgeologiya' and the NOAA US Antartctic Marine Living Resources (AMLR) program team for help with logistics and sample collection, M. Østensen for DGGE analysis, S. Lierhagen for HR-ICP-MS analysis, S. Norland for the Gel2k program and C. Harrod for comments on an earlier version of the manuscript. This project was funded by the Norwegian Polar Institute (grant 3557-103, E.S.) and the US AMLR Program, administered by the Antarctic Ecosystem 
Research Division at NOAA's Southwest Fisheries Research Center, La Jolla, CA, USA, under grant NA17RJ1231 (O.H.H.). Views contained herein are those of the authors and do not reflect those of NPI or NOAA.

\section{LITERATURE CITED}

Ardelan MV, Holm-Hansen O, Hewes CD, Reiss CS and others (2010) Natural iron enrichment around the Antarctic Peninsula in the Southern Ocean. Biogeosciences 7:11-25

- Armand LK, Cornet-Barthaux V, Mosseri J, Queguiner B (2008) Late summer diatom biomass and community structure on and around the naturally iron-fertilised Kerguelen Plateau in the Southern Ocean. Deep-Sea Res II 55:653-676

- Bodungen BV, Smetacek VS, Tilzer MM, Zeitzschel B (1986) Primary production and sedimentation during spring in the Antarctic Peninsula region. Deep-Sea Res 33:177-194

Clarke KR (1993) Non-parametric multivariate analyses of changes in community structure. Aust J Ecol 18:117-143

> Díez B, Pedrós-Alió C, Marsh TL, Massana R (2001) Application of denaturing gradient gel electrophoresis (DGGE) to study the diversity of marine picoeukaryotic assemblages and comparison of DGGE with other molecular techniques. Appl Environ Microbiol 67:2942-2951

> Díez B, Massana R, Estrada M, Pedrós-Alió C (2004) Distribution of eukaryotic picoplankton assemblages across hydrographic fronts in the Southern Ocean, studied by denaturing gradient gel electrophoresis. Limnol Oceanogr 49:1022-1034

> Dulaiova H, Ardelan MV, Henderson PB, Charette MA (2009) Shelf-derived iron inputs drive biological productivity in the southern Drake Passage. Global Biogeochem Cycles 23:GB4014, doi:10.1029/2008GB003406

Emery WJ 2001: Water types and water masses. In: Steele $\mathrm{JH}$, Thorpe SA, Turekian KK (eds) Encyclopedia of ocean sciences. Academic Press, San Diego, CA, p 3179-3187

Finlay BJ (2002) Global dispersal of free-living microbial eukaryote species. Science 296:1061-1063

Fromin N, Hamelin J, Tarnawski S, Roesti D and others (2002) Statistical analysis of denaturing gel electrophoresis (DGE) fingerprinting patterns. Environ Microbiol 4: 634-643

> Garrison DL (1991) An overview of the abundance and role of protozooplankton in Antarctic waters. J Mar Syst 2: 317-331

Gast RJ, Dennett MR, Caron DA (2004) Characterization of protistan assemblages in the Ross Sea, Antarctica, by denaturing gradient gel electrophoresis. Appl Environ Microbiol 70: 2028-2037

> Hamilton AK, Lovejoy C, Galand PE, Ingram RG (2008) Water masses and biogeography of picoeukaryote assemblages in a cold hydrographically complex system. Limnol Oceanogr 53:922-935

Hewes CD (2010) Quantitative microbial ecology off the northern Antarctic Peninsula. PhD dissertation, University of Bergen, available at http://hdl.handle.net/1956/ 3992

Hewes CD, Holm-Hansen O, Sakshaug E (1985) Alternate carbon pathways at lower trophic levels in the Antarctic food-web. In: Siegfried WR, Condy PR, Laws RM (eds) Antarctic nutrient cycles and food webs, 4th Symp on Antarctic Biology (SCOR/SCAR), Wilderness, South
Africa, 1983. Springer-Verlag, Berlin, p 277-283

> Hewes CD, Sakshaug E, Holm-Hansen O, Reid FMH (1990) Microbial autotrophic and heterotrophic eucaryotes in Antarctic Waters: relationships between biomass and chlorophyll, adenosine triphosphate and particulate organic carbon. Mar Ecol Prog Ser 63:27-35

> Hewes CD, Reiss CS, Kahru M, Mitchell BG, Holm-Hansen O (2008) Control of phytoplankton biomass by dilution and mixing depth in the western Weddell-Scotia Confluence. Mar Ecol Prog Ser 366:15-29

Hewes CD, Reiss CR, Holm-Hansen O (2009) A quantitative analysis of sources for summertime phytoplankton variability over 18 years in the South Shetland Islands (Antarctica) region. Deep-Sea Res I 56:1230-1241

> Holm-Hansen O, Hewes CD (2004) Deep chlorophyll-a maxima (DCMs) in Antarctic waters: I. Relationships between DCMs and the physical, chemical, and optical conditions in the upper water column. Polar Biol 27: $699-710$

> Holm-Hansen O, Riemann B (1978) Chlorophyll a determination: improvements in methodology. Oikos 30:438-447

> Holm-Hansen O, Hewes CD, Villafane VE, Helbling EW, Silva N, Amos T (1997) Distribution of phytoplankton and nutrients in relation to different water masses in the area around Elephant Island, Antarctica. Polar Biol 18: $145-153$

> Hopkinson BM, Mitchell BG, Reynolds RA, Wang $\mathrm{H}$ and others (2007) Iron limitation across chlorophyll gradients in the southern Drake Passage: phytoplankton responses to iron addition and photosynthetic indicators of iron stress. Limnol Oceanogr 52:2540-2554

> Jamieson RE, Rogers AD, Billett DSM, Smale DA, Pearce DA (2012) Patterns of marine bacterioplankton biodiversity in the surface waters of the Scotia Arc, Southern Ocean. FEMS Microbiol Ecol 80:452-68

> Kang SH, Kang JS, Lee S, Chung KH, Kim D, Park MG (2001) Antarctic phytoplankton assemblages in the marginal ice zone of the northwestern Weddell Sea. J Plankton Res 23:333-352

> Langenheder S, Jürgens K (2001) Regulation of bacterial biomass and community structure by metazoan and protozoan predation. Limnol Oceanogr 46:121-134

Legendre P, Legendre L (1998) Numerical ecology (developments in environmental modeling) 2nd edn. Elsevier, Oxford

Lindström ES, Langenheder S (2012) Local and regional factors influencing bacterial community assembly. Environ Microbiol Rep 4:1-9

Lipsky JD (ed) (2007) AMLR2006/2007 field season report, objectives, accomplishments, and tentative conclusions. NOAA Tech Memo NMFS-SWFSC-409

> Martiny JBH, Bohannan BJM, Brown JH, Colwell RK and others (2006) Microbial biogeography: putting microorganisms on the map. Nat Rev Microbiol 4:102-112

> Mendes CFB, Silva de Souza M, Tavano Garcia VM, Costa Leal M, Brotas V, Eiras Garcia CA (2012) Dynamics of phytoplankton communities during late summer around the tip of the Antarctic Peninsula. Deep-Sea Res I 65: $1-14$

> Murray AE, Preston CM, Massana R, Taylor LT, Blakis A, Wu K, DeLong EF (1998) Seasonal and spatial variability of bacterial and archaeal assemblages in the coastal waters near Anvers Island, Antarctica. Appl Environ Microbiol 64:2585-2595

Muyzer G, Smalla K (1998) Application of denaturing 
gradient gel electrophoresis (DGGE) and temperature gradient gel electrophoresis (TGGE) in microbial ecology. Antonie van Leeuwenhoek 73:127-141

Muyzer G, de Waal EC, Uitterlinden AG (1993) Profiling of complex microbial populations by denaturing gradient gel electrophoresis analysis of polymerase chain reaction-amplified genes coding for 16S rRNA. Appl Environ Microbiol 59:695-700

Olguin HF, Alder VA (2011) Species composition and biogeography of diatoms in antarctic and subantarctic (Argentine shelf) waters. Deep-Sea Res II 58:139-152

Ovreås L, Forney L, Daae FL, Torsvik V (1997) Distribution of bacterioplankton in meromictic Lake Saelenvannet, as determined by denaturing gradient gel electrophoresis of PCRamplified gene fragments coding for 16S rRNA. Appl Environ Microbiol 63:3367-3373

Pinhassi J, Winding A, Binnerup SJ, Zweifel UL, Riemann B, Hagström $\AA$ (2003) Spatial variability in bacterioplankton community composition at the Skagerrak-Kattegat Front. Mar Ecol Prog Ser 255:1-13

Pinhassi J, Sala MM, Havskum H, Peters F, Guadayol O, Malits A, Marrase C (2004) Changes in bacterioplankton composition under different phytoplankton regimens. Appl Environ Microbiol 70:6753-6766

R Development Core Team (2008) R: a language and environment for statistical computing. R Foundation for Sta-

Editorial responsibility: Eva Lindström, Uppsala, Sweden tistical Computing, Vienna, available at www.R-project. org.

Reiss CS, Hewes CD, Holm-Hansen O (2009) Influence of atmospheric teleconnections and Upper Circumpolar Deep Water on phytoplankton biomass around Elephant Island, Antarctica. Mar Ecol Prog Ser 377:51-62

Sanudo-Wilhelmy SA, Olsen KA, Scelfo JM, Foster TD, Flegal AR (2002) Trace metal distributions off the Antarctic Peninsula in the Weddell Sea. Mar Chem 77:157-170

Thompson AF, Heywood KJ, Thorpe SE, Renner AHH, Trasviña A (2009) Surface circulation at the tip of the Antarctic Peninsula from drifters. J Phys Oceanogr 39: $3-26$

Vadstein O (2011) Large variation in growth-limiting factors for marine heterotrophic bacteria in the Arctic waters of Spitsbergen ( $\left.78^{\circ} \mathrm{N}\right)$. Aquat Microb Ecol 63:289-297

Vincent WF, Bowman JP, Rankin LM, McMeekin TA (2000) Phylogenetic diversity of picocyanobacteria in Arctic and Antarctic ecosystems. In: Bell CR, Brylinsky M, JohnsonGreen P (eds) Proc 8th Int Symp on Microbial Ecology. Atlantic Canada Society for Microbial Ecology, Halifax, p $317-322$

> West NJ, Obernosterer I, Zemb O, Lebaron P (2008) Major differences of bacterial diversity and activity inside and outside of a natural iron-fertilized phytoplankton bloom in the Southern Ocean. Environ Microbiol 10:738-756

Submitted: December 18, 2012; Accepted: June 11, 2013 Proofs received from author(s): August 15, 2013 